\title{
The Incidence of Fusarium graminearum in Wild Grasses is Associated With Rainfall and Cumulative Host Density in New York
}

\author{
Michael R. Fulcher, James B. Winans, Menchus Quan, and Gary C. Bergstrom ${ }^{\dagger}$ \\ School of Integrative Plant Science, Plant Pathology and Plant-Microbe Biology Section, Cornell University, Ithaca, NY 14853- \\ 5904
}

\begin{abstract}
The movement of plant pathogens between cultivated and natural host communities can result in lost agricultural production and altered microbial or plant biodiversity. Fusarium graminearum incidence was studied in wild grass hosts for 3 years to better understand the ecology of this plant pathogen at the interface of crop fields and nonagricultural environments. Research sites $(n=23)$ were spread between regions of high and low agricultural production and included both agricultural and nonagricultural fields. Pathogen incidence in living grass spikes and senesced, overwintered stems varied between regions of New York and was lowest in a region with sparser agricultural production $(P=0.001)$. However, pathogen incidence within regions was similar at both agricultural and

in the 8 weeks preceding sample collection was strongly correlated with $F$. graminearum incidence in grasses, as well as an increased prevalence of $F$. graminearum in Fusarium spp. communities $(P=0.001)$. Grass species diversity was not associated with a reduction in pathogen incidence, and $F$. graminearum incidence did not vary among the most well-sampled grasses. These results indicate the pathogen colonizes and spreads in noncultivated grasses in a manner consistent with existing concepts of pathogen epidemiology in cereal crops. Increasing host acreage, whether cultivated or not, could drive the colonization of grasses in remote or protected environments, potentially altering their microbial communities.
\end{abstract} nonagricultural sites. The groundcover of crop and wild hosts within $1 \mathrm{~km}$ of sample sites were equally effective predictors of pathogen incidence, indicating either host group may drive pathogen spread. Rainfall
Keywords: Fusarium graminearum, wild hosts, dilution, spillover, grasses, ecology, epidemiology
The movement of plant pathogens across the interface of crop land and natural spaces has consequences for agricultural productivity and the maintenance of biodiversity. Pathogens can move from cultivated plants to nonmanaged wild hosts (Gilbert and Hubbell 1996), uncultivated hosts can act as pathogen reservoirs that contribute to disease in managed host communities (Wisler and Norris 2005), and in some instances, pathogen movement occurs in both directions (Fabiszewski et al. 2010).

The 'spillover' of pathogens from one host to another can be an important determinant of pathogen prevalence (Plantegenest et al. 2007; Young et al. 2017) and have significant impacts on host communities (Beckstead et al. 2010; Borer et al. 2010; Flory et al. 2011; Meentemeyer et al. 2008; Mordecai 2013). Understanding crossenvironmental interactions may inform disease management, environmental conservation efforts, and land use decisions. While these interactions have been observed in some specific plant-pathogen systems, several referenced above, phytopathogen lifestyles are diverse and remain underrepresented in this field of study. Accounting for the breadth of their life histories is important to our understanding

${ }^{\dagger}$ Corresponding author: G. Bergstrom; gcb3@ cornell.edu

Funding: This material is based upon work supported by the U.S. Department of Agriculture Agricultural Research Service under Agreement No. 59-02064-006, a cooperative project with the U.S. Wheat and Barley Scab Initiative, and USDA National Institute for Food and Agriculture Hatch Project NYC153437. Any opinions, findings, conclusions, or recommendations expressed in this publication are those of the author(s) and do not necessarily reflect the view of the U.S. Department of Agriculture. Funding was also provided by the College of Agriculture and Life Sciences, Cornell University, through a Cornell Kieckhefer Adirondack Fellowship and an Andrew W. Mellon Student Research Grant.

The author(s) declare no conflict of interest.

Accepted for publication 6 April 2020.

C 2020 The American Phytopathological Society of specific cases as well as our general understanding of disease ecology (Gilbert 2002).

Dilution and amplification effects stemming from varying levels of host biodiversity are also known to impact disease incidence (Keesing et al. 2006; Ostfeld and Keesing 2012). A dilution effect is predicated on variation in the susceptibility of different host species, so generalist pathogens that are well adapted to diverse hosts may not be subject to this effect. The interaction of biodiversity and disease risk should continue to be evaluated in different pathosystems to determine when generalized rules may apply (Cardinale et al. 2012; Salkeld et al. 2013), and the interface of cropland and natural plant communities is a particularly relevant setting to explore how altered host biodiversity may impact the spread of disease in managed and nonmanaged environments.

This project examined pathogen-host community interactions, including potential spillover and dilution effects, of the broad host range fungal pathogen Fusarium graminearum Schwabe. A cosmopolitan species primarily understood as a pathogen of small grains and maize (Goswami and Kistler 2004), F. graminearum is capable of infecting dozens of plant species, the majority of which are true grasses in the family Poaceae (Farr and Rossman 2019). Many of these are noncultivated species, ubiquitous across landscapes and often found in close proximity to susceptible crops. In addition to directly damaging crops, $F$. graminearum contaminates grain and stover with toxins that can render them unfit for human and animal consumption (Marasas et al. 1984). Annual economic losses are estimated at $\$ 1$ billion in the United States (Wilson et al. 2017). Current disease management practices rely heavily on fungicides (Wegulo et al. 2015) and are largely based on our understanding of pathogen biology and ecology in an exclusively agricultural context. Airborne spores capable of kilometer scale dispersal (Keller et al. 2014; Maldonado-Ramirez et al. 2005) incite disease on flowering cereal spikes annually, and the pathogen persists from year to year on the dead tissue of its hosts, most importantly corn stalks, until environmental conditions are appropriate for the discharge of propagules. While the occurrence and pathogenicity of $F$. graminearum on many grasses is well documented, and much is understood about the pathogen's behavior in agricultural systems, population level interactions 
with wild hosts and the connection between noncultivated and cultivated hosts have not been thoroughly investigated. This relationship is important to disease prediction and management.

Through a survey of naturally occurring grasses, host community characteristics and environmental conditions were identified that influence $F$. graminearum incidence in noncultivated grass species. It was hypothesized that $F$. graminearum incidence in wild grasses would be higher in agricultural fields than natural sites, higher in a region with greater crop production than in a region with less agricultural production, and positively correlated with local host

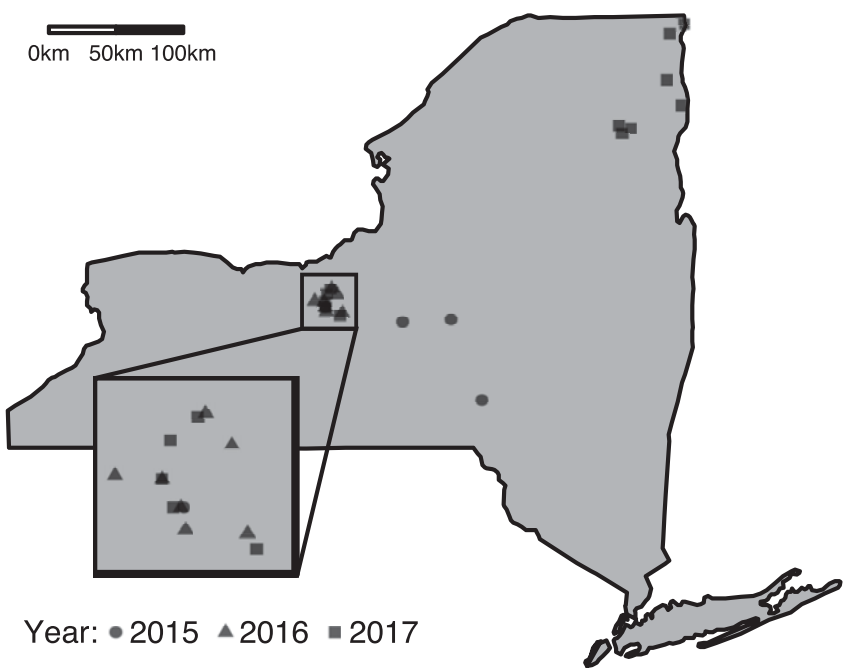

Fig. 1. Wild grass spikes were collected from 23 field sites from 2015 to 2017. During 2016 to 2017 , wild grass stems that had overwintered naturally were collected from 18 of these sites. Sampling locations were divided between two regions of New York and two land uses, agricultural and natural. groundcover and estimated rainfall in the weeks prior to flowering. The potential for pathogen spillover between host communities was examined using host ground cover estimates and land use categories. Grass host diversity at sampling sites was also used to test for a dilution effect in this system. Finally, the ratio of $F$. graminearum to other Fusarium spp. inhabiting grass spikes was recorded to observe the influence of host community and environment on related microbes inhabiting the same ecological niche as this pathogen.

\section{Materials and Methods}

Research sites. Wild grass debris and inflorescences were collected from the borders of small grains fields and natural preserves in two regions of New York during the 2015 to 2017 growing seasons. Twenty unique locations were sampled, and one extensive, natural grassland (Montezuma National Wildlife Refuge) was revisited in all three years (Fig. 1). In 2015, three agricultural fields and Montezuma Refuge in central NY were sampled. In 2016, the same refuge was sampled along with five different agricultural fields. In 2017, research locations were divided between central and northeastern NY to include sites in regions with different levels of agricultural production. The agricultural landscape in central NY is dominated by corn and soybean, while northeastern NY has a lower field crop acreage and is characterized by the wilderness of the Adirondack Mountains. Three agricultural fields and four natural spaces were sampled in the northeast region, and three agricultural fields and two natural spaces were sampled in the central region. These regions also differed in altitude and temperature. Northeastern NY has lower mean temperatures and several sites were situated at a higher elevation than those found in central NY.

Winter wheat was grown at the majority of agricultural sites. One location contained winter barley, and two others were Cornell University research farms growing multiple small grain crops. Fields ranged in size from 8 to 154 acres $(\bar{x}=32)$, and all but two had a history of wheat-corn-soybean rotations. Crop management practices varied, but fungicide applications were rare. Sites were separated

Table 1. Host species sampled with total percent incidence of Fusarium graminearum

\begin{tabular}{|c|c|c|c|c|}
\hline Year & Grass species & Sites $^{\mathbf{a}}$ & Spikes & Incidence $(\%)$ \\
\hline \multirow[t]{5}{*}{2015} & Bromus inermis Leyss. & 3 & 64 & 76.60 \\
\hline & Elymus canadensis $\mathrm{L}$. & 1 & 5 & 40.00 \\
\hline & Hordeum jubatum $\mathrm{L}$. & 1 & 20 & 15.00 \\
\hline & Phalaris arundinacea $\mathrm{L}$. & 1 & 7 & 28.60 \\
\hline & Phleum pretense $\mathrm{L}$. & 2 & 45 & 35.60 \\
\hline \multirow[t]{9}{*}{2016} & B. commutatus L. & 2 & 36 & 0.00 \\
\hline & B. inermis & 4 & 247 & 2.02 \\
\hline & Dactylis glomerata L. & 6 & 288 & 3.47 \\
\hline & E. repens & 5 & 133 & 0.00 \\
\hline & Festuca spp. & 4 & 98 & 1.02 \\
\hline & H. jubatum & 1 & 29 & 0.00 \\
\hline & P. arundinacea & 5 & 188 & 1.06 \\
\hline & $P$. pratense & 4 & 101 & 0.00 \\
\hline & Роа аппиа $\mathrm{L}$ & 2 & 70 & 1.43 \\
\hline \multirow[t]{15}{*}{2017} & Alopecurus arundinaceus Poir. & 1 & 14 & 0.00 \\
\hline & Brachypodium sylvaticum (Huds.) P. Beauv. & 2 & 21 & 0.00 \\
\hline & B. commutatus & 2 & 46 & 30.43 \\
\hline & B. inermis & 7 & 201 & 17.91 \\
\hline & B. secalinus $\mathrm{L}$. & 1 & 5 & 20.00 \\
\hline & D. glomerata & 9 & 287 & 52.26 \\
\hline & E. repens & 10 & 392 & 15.56 \\
\hline & Festuca spp. & 11 & 259 & 16.22 \\
\hline & H. jubatum & 1 & 10 & 10.00 \\
\hline & Lolium perenne $\mathrm{L}$. & 2 & 15 & 0.00 \\
\hline & Panicum spp. & 5 & 55 & 5.45 \\
\hline & P. arundinacea & 11 & 332 & 23.80 \\
\hline & P. pratense & 10 & 332 & 11.14 \\
\hline & Р. аппиа & 8 & 130 & 10.77 \\
\hline & Typha latifolia $\mathrm{L}$. & 1 & 5 & 0.00 \\
\hline
\end{tabular}

\footnotetext{
a Number of field sites where each species was found.
} 
by a minimum distance of $1 \mathrm{~km}$, and the furthest distance between sites was $346 \mathrm{~km}$. The natural preserves sampled were primarily public wildlife management areas selected for the presence of grass hosts and their proximity to agricultural sites. For the duration of this study, these areas were subject to minimal management practices aimed at protecting wildlife habitat.

Sample collection. Inflorescence sampling focused on grass species that flower simultaneously with winter wheat (Table 1) and was timed to coincide with the 'early grain filling' growth stage (Zadoks GS 83 to 85) in nearby wheat crops (Large 1954), by which time the majority of crop infections are thought to have occurred. Grass spikes were collected at a single time point from each site, and all sites within a region were sampled in a single week. In 2015, wild grass spikes were collected randomly from each site. In 2016 and 2017, $1 \mathrm{~m}^{2}$ quadrats were laid at regular intervals on transects following the grassy margins of agricultural fields or accessible portions of natural grasslands. Quadrats were separated by $10 \mathrm{~m}$, so the number of quadrats per site ( $n=8$ to 50 ) increased with the boundary length of agricultural fields or the size of natural preserves. Spikes ( $n=5$ to 20 ) from each grass species present in a quadrat were collected. Only spikes between flowering and maturity were taken to ensure colonization could have occurred but the fungus was not present as a saprophyte on senesced tissue. Senesced, overwintered grass stems were collected in early May before disease epidemics began in field crops. Sampling was conducted in quadrats laid as described above but independently of those for spike sampling. All senesced stems that contained at least one node or joint were collected from within each quadrat. No stem samples were collected in 2015, and one site in 2017 did not contain enough stem material for adequate sampling.

Table 2. Fusarium graminearum incidence in grass stems, analysis of variance output

\begin{tabular}{lccc}
\hline Predictor & $\boldsymbol{\chi}^{\mathbf{2}}$ & Degrees of freedom & $\boldsymbol{P}$-value \\
\hline Year & 5.155 & 1 & $\mathbf{0 . 0 2 3}$ \\
Land use & 0.050 & 1 & 0.822 \\
Region & 11.918 & 1 & $\mathbf{0 . 0 0 1}$ \\
\hline
\end{tabular}

a Values in bold are significant $(P<0.05)$.
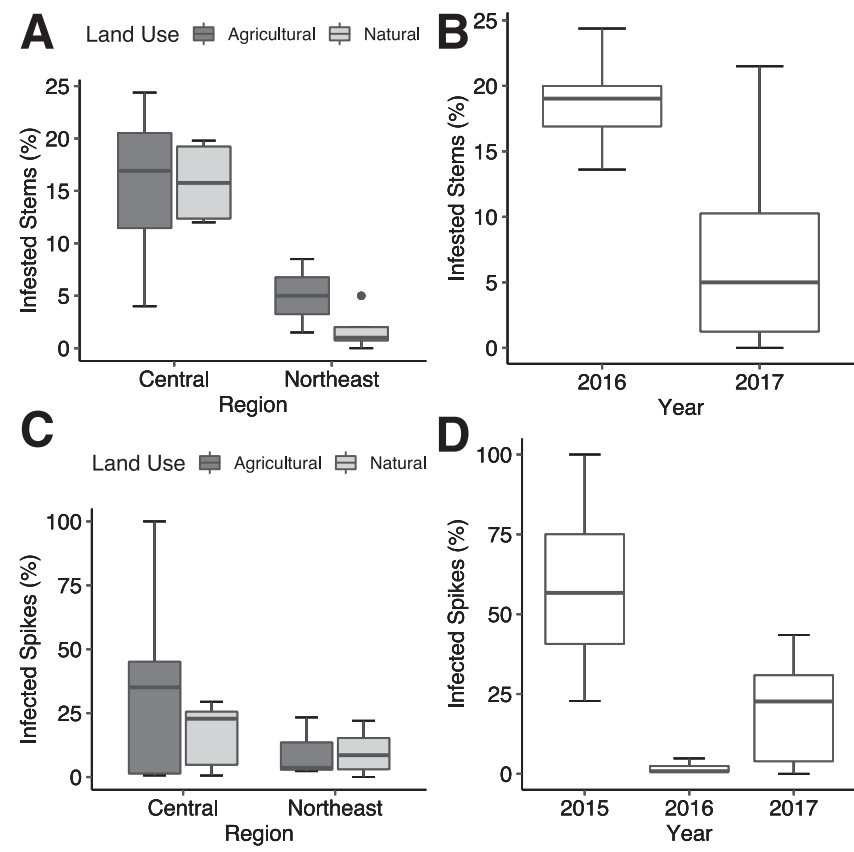

Fig. 2. Fusarium graminearum recovery rates from $\mathbf{A}-\mathbf{B}$, infested grass stems and $\mathbf{C}$ $D$, infected grass spikes. Lower pathogen incidence was recorded in a region with little agricultural production as compared with a region with intensive crop production. Differences between land uses were not detected, and year-to-year variation was high.
All samples were stored at $-20^{\circ} \mathrm{C}$ for at least one week to remove arthropods and inhibit tissue degradation, then kept at $4^{\circ} \mathrm{C}$ during processing. Ten to 20 pieces of stem tissue from each quadrat and five to 10 grass spikes per species from each quadrat were chosen at random and tested for $F$. graminearum incidence. Plant tissues were rinsed in sterile water to remove coarse debris, surface sterilized in $1.65 \% \mathrm{NaOCl}$ for $2 \mathrm{~min}$, rinsed again in sterile water, and placed on potato dextrose agar amended with streptomycin $(0.24 \mathrm{~g} /$ liter $)$ and neomycin $(0.2 \mathrm{~g} /$ liter $)$ to inhibit bacterial growth. Fusarium spp. colonies growing from plant tissue were subcultured, $F$. graminearum sensu lato was identified morphologically, and species group identity was confirmed for representative isolates by EF-1-alpha sequence homology (GenBank: MK937924-MK937943) (Leslie and Summerell 2006).

Host community and environmental data. The host species richness of each site sampled in 2016 and 2017 was determined by recording species presence in quadrats laid during spike sampling. Grass species identification was performed in the field based on floral morphology and growth habit. Grasses that could not be identified in the field were compared with preserved specimens at the Liberty Hyde Bailey Conservatory (Ithaca, NY). Local host density was measured as the percent ground cover of corn, aggregated small grains, grasses, or all three hosts within a $1 \mathrm{~km}$ radius of each field site during the year preceding sample collection. This host density was assumed to correlate with the amount of pathogen inoculum being produced on debris during the year spike samples were collected. The acreage estimates were taken from publicly available ground cover data downloaded in a georeferenced TIFF format (USDA National Agricultural Statistics Service 2019). Pixels were counted and converted to acres in QGIS version 3.4.7 (QGIS Development Team 2013). Cumulative rainfall estimates for the 8 weeks prior to spike sampling were calculated from an interpolated climate data set available from the PRISM climate group at Oregon State (http://prism.oregonstate. edu/).

Statistical analysis. All analyses were performed in $\mathrm{R}$ version 3.5.3 (R Core Team 2019). Pathogen incidence in stems and spikes was analyzed with a series of generalized linear models. First, pathogen presence or absence in individual pieces of host tissue was analyzed in response to fixed effects for year, land use, and region plus a random effect for sampling sites. Wald's $\chi^{2}$ statistic was used to determine predictor significance. Following this analysis, spike incidence was modeled again, using continuous predictors. Rainfall, host density, an interaction between the two, and rarefied host species richness were included as fixed effects. The random effect of sample site was retained. This model was run four times to separately include each class of host density (corn, small grains, grass, and total host acreage). The model with the lowest AIC value was used to generate confidence intervals and estimated probabilities for pathogen presence across different host density and rainfall values. A model containing the same predictors was then used to analyze the ratio of $F$. graminearum to other Fusarium species at each site. The response variable was coded as a binomial with success being a Fusarium isolate identified as $F$. graminearum and a failure being the identification of any other Fusarium sp. The $\mathrm{R}^{2}$ of all models was calculated with the 'piecewiseSEM' package (Lefcheck 2016). Effective species numbers, or Hill numbers (qD), were calculated from observed host species richness using the 'iNEXT' package at orders from 0-2 (Hsieh et al. 2016). Values for effective species at each order were correlated with $F$. graminearum incidence to assess whether disease dilution occurred with increasing host diversity.

Table 3. Fusarium graminearum incidence in grass spikes, analysis of variance output

\begin{tabular}{lrcr}
\hline Predictor & $\boldsymbol{\chi}^{\mathbf{2}}$ & Degrees of freedom & $\boldsymbol{P}$-value $^{\mathbf{a}}$ \\
\hline Year & 55.987 & 2 & $<\mathbf{0 . 0 0 1}$ \\
Land use & 0.746 & 1 & 0.388 \\
Region & 11.089 & 1 & $\mathbf{0 . 0 0 1}$ \\
\hline
\end{tabular}

${ }^{a}$ Values in bold are significant $(P<0.05)$. 


\section{Results}

Wild grass stems collected from 19 sites over two years were infested with $F$. graminearum at a rate of $13.4 \%(n=3,671)$. Year and region were significant predictors of infestation $(P \leq 0.020)$, but no difference was detected between land uses (Table 2, Fig. 2A, B). Pathogen incidence in spikes collected from 23 sites over three years was $15.4 \%(n=3,435)$. Year and region were again significant predictors of pathogen incidence $(P \leq 0.001)$, while land use had no effect on incidence (Table 3, Fig. 2C, D).

Host density and rainfall varied between locations and years (Fig. 3). Models of spike incidence using corn, small grains, grass, and total host acreage within $1 \mathrm{~km}$ of sampling sites performed similarly (Table 4). The model using total host acreage had the lowest AIC value so was chosen for use in further analyses. A significant interaction was detected between rainfall and host density $(P=0.014)$, and a high probability of spike infection was expected when both rainfall and host density were greatest (Table 5, Fig. 4). The same model was applied to the probability of a recovered Fusarium species being identified as $F$. graminearum. The estimated probabilities are displayed in Figure 5 and were significantly impacted by the interaction of rainfall and host $\left(F_{23,1}=7.172 ; P<0.001\right)$. Host richness did not have a significant effect on pathogen incidence and showed a slight positive correlation with $F$. graminearum incidence in spikes (Fig. 6). The incidence of $F$. graminearum in grasses sampled at 10 or more sites with a sample size greater than 100 spikes ranged from 7.50 to $27.82 \%$ (Table 6).

\section{Discussion}

This study characterized the incidence of a widely dispersed, broad host range pathogen in noncultivated grasses across different environments. Our survey found that $F$. graminearum is present in

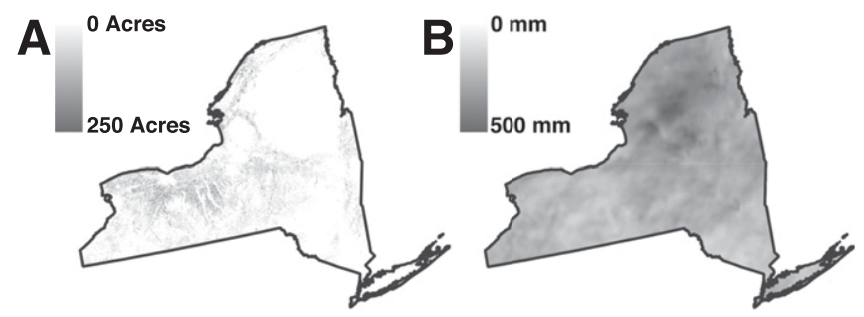

Fig. 3. Maps of the 2017 environmental data used to model pathogen incidence in grass spikes. A, Crop density within $1 \mathrm{~km}$ of sample sites was lower in northeastern New York. B, Cumulative rainfall in the 8 weeks prior to sample collection varied between sites. Interpolated rainfall data were taken from the PRISM Climate Group at Oregon State.

Table 4. Model comparison using continuous predictors of Fusarium graminearum spike incidence in noncultivated grass

\begin{tabular}{lccc}
\hline Host class & Model AIC & $\mathbf{R}^{\mathbf{2}}$ (fixed) & $\mathbf{R}^{\mathbf{2}}$ (fixed and random) \\
\hline Corn & 141.865 & 0.34 & 0.47 \\
Small grains & 144.008 & 0.34 & 0.48 \\
Grasses & 140.331 & 0.37 & 0.48 \\
All hosts & 139.296 & 0.36 & 0.47 \\
\hline
\end{tabular}

Table 5. Fusarium graminearum incidence in grass spikes modeled with continuous predictors, analysis of variance output

\begin{tabular}{lrcr}
\hline Predictor & $\boldsymbol{\chi}^{\mathbf{2}}$ & Degrees of freedom & $\boldsymbol{P}_{\text {-value }}^{\mathbf{a}}$ \\
\hline Effective species & 2.285 & 1 & 0.131 \\
Host density & 1.052 & 1 & 0.305 \\
Rainfall & 35.244 & 1 & $<\mathbf{0 . 0 0 1}$ \\
Density:rainfall & 5.980 & 1 & $\mathbf{0 . 0 1 4}$ \\
\hline
\end{tabular}

a Values in bold are significant $(P<0.05)$. common, noncultivated grasses throughout New York. Pathogen incidence was lower in a region with low agricultural production than in a region with high agricultural production, as anticipated, but did not vary between agricultural and nonagricultural sites. The incidence of this pathogen in grass spikes was positively correlated with cumulative host density and rainfall. Agricultural and nonagricultural

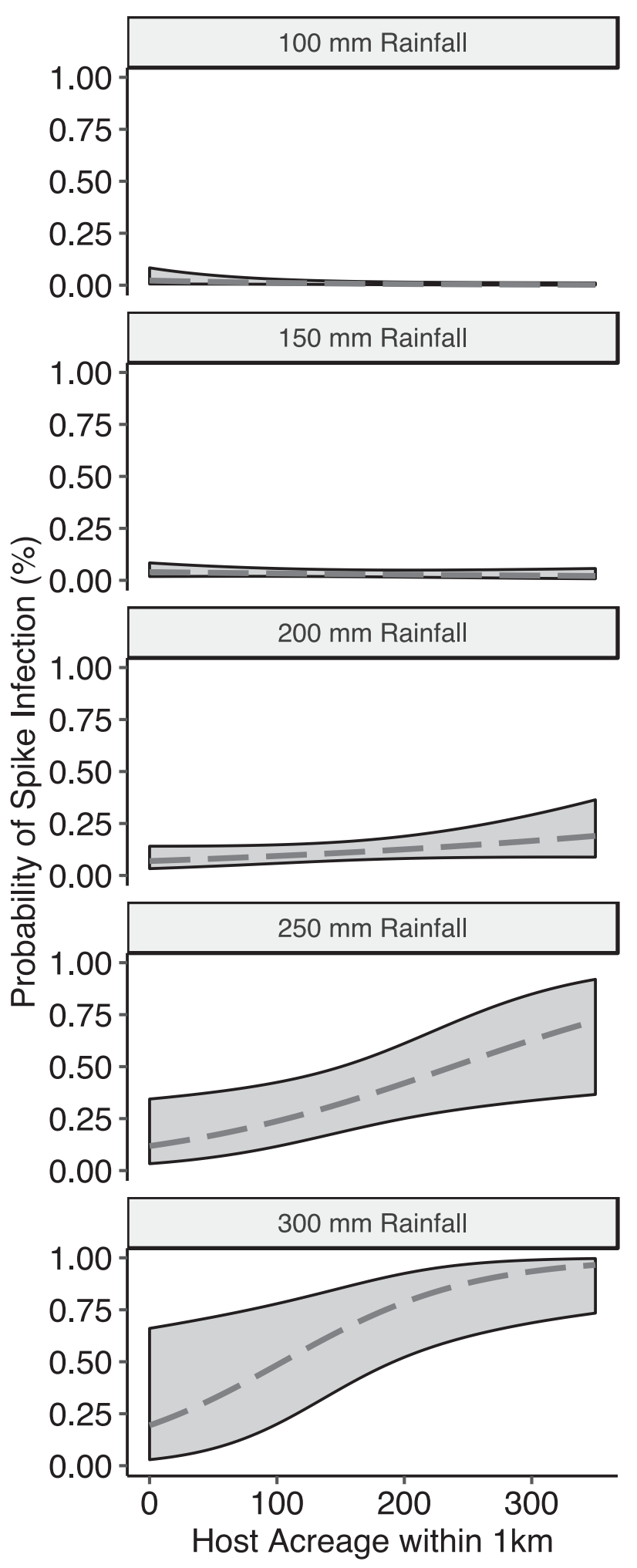

Fig. 4. The probability of spike infection with $F$. graminearum was predicted by the interaction of host density and rainfall in the 8 weeks prior to sampling. Confidence intervals $(95 \%)$ around least-squares means are displayed for increasing rainfall and host density. The range of host density and rainfall values displayed represents field conditions observed during the course of this study. 
host density were both implicated as supporting $F$. graminearum presence by their value to descriptive models, which does not suggest that one-sided spillover events drive infection in either group of hosts. The incidence of the pathogen did not vary with grass host diversity, providing no evidence of a biodiversity driven dilution effect. The dispersal of $F$. graminearum is favored by high rainfall and may lead to changes in Fusarium spp. communities inhabiting

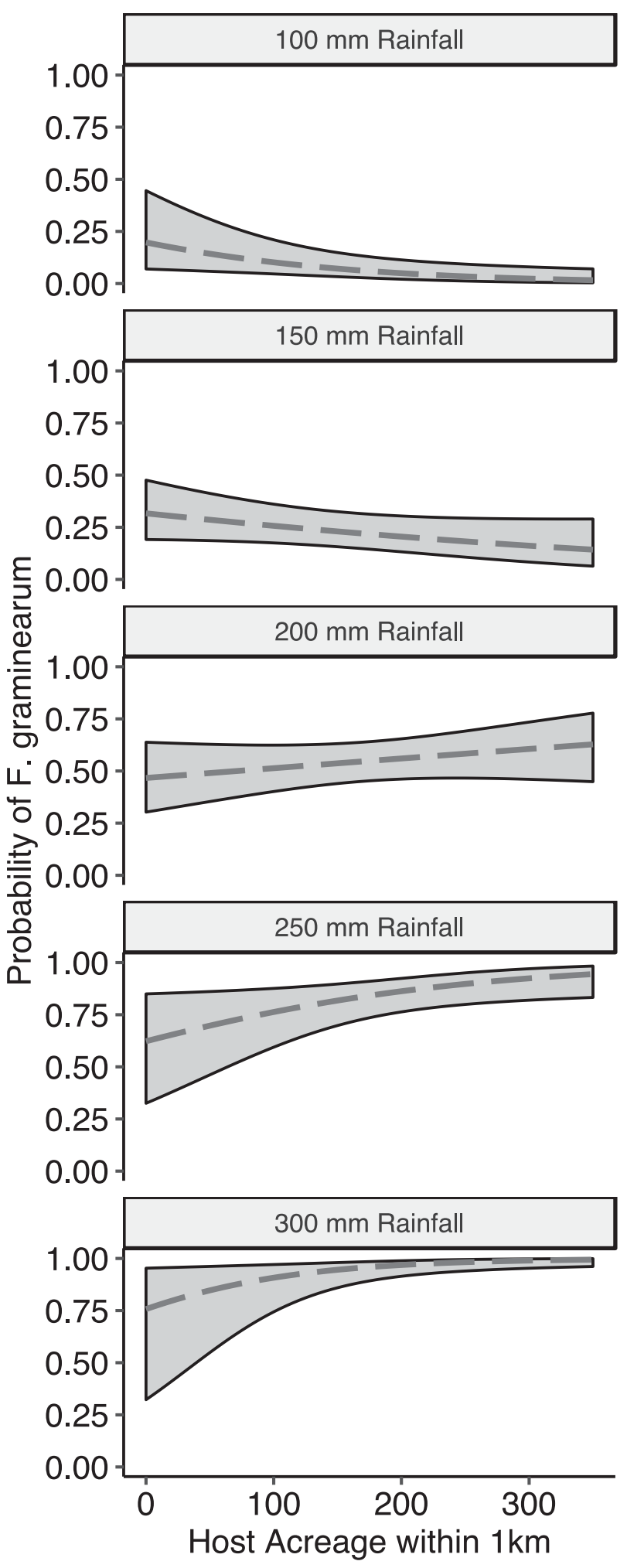

Fig. 5. The probability of a Fusarium sp. isolated from wild grass being F. graminearum increased as host density and rainfall increased. The incidence of other fusaria did not increase alongside the incidence of $F$. graminearum. Confidence intervals (95\%) around least-squares means are displayed for increasing rainfall and host density. noncultivated grasses, depending on rainfall and host density as predicted by our model.

On average, the rate of pathogen incidence recorded here agrees with past observations about $F$. graminearum colonization of grasses, in which estimates ranged from 15 to $30 \%$ (Inch and Gilbert 2003; Lofgren et al. 2017; Szécsi et al. 2013; Turkington et al. 2011).
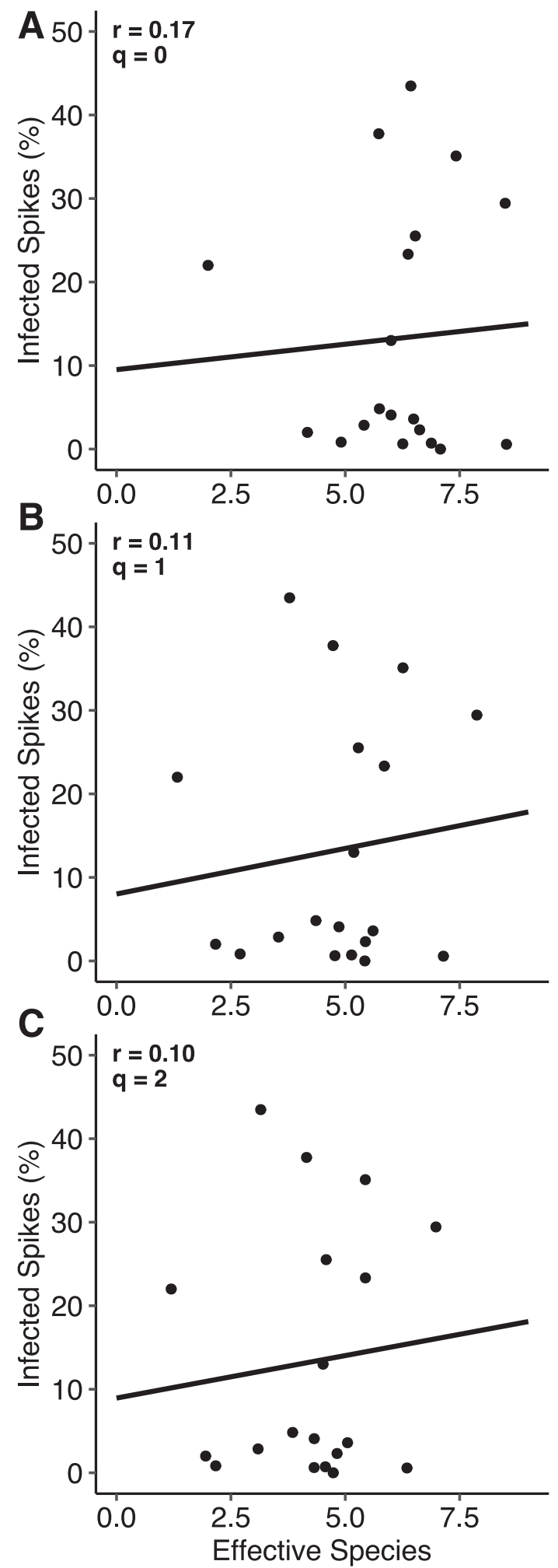

Fig. 6. Host species diversity was not associated with a decline in pathogen incidence as predicted by a dilution hypothesis. The correlation of Fusarium graminearum incidence and effective species number was low and insignificant. Effective species numbers, or Hill numbers $(q D)$, were calculated on orders $\mathbf{A}, q=0 ; B, q=1$; and $C, q=2$, which vary in the weight given to rare species. 
We observed high incidence in wild grass inflorescences only under conditions similar to those resulting in disease epidemics in crops. The weather in 2015 and 2017 was conducive to infection, while a severe drought in 2016 likely limited disease pressure because both propagule dispersal and the infection process require moisture (Manstretta et al. 2016; Manstretta and Rossi 2015). The low rates of disease in 2016 also may have reduced pathogen colonization of plant stem tissue, resulting in the lower recovery rates from overwintered stems in 2017.

An increase in corn residues left in agricultural fields and the adoption of reduced tillage agriculture has been connected to the reemergence of Fusarium head blight as a disease of concern in cereal crops (McMullen et al. 1997). Previous observational evidence about pathogen incidence in grasses led to the hypothesis that spillover occurs from crops to noncultivated grasses. Inch and Gilbert (2003) found no $F$. graminearum when sampling wild grasses from a single urban environment and suggested this could be a result of distance from agricultural production. Turkington et al. (2011), sampling senesced grass stems, found only those in a corn producing region contained $F$. graminearum. A crop-to-grass spillover hypothesis would have been supported by low pathogen incidence in a region with less agricultural production, which was observed, and lower incidence in nonagricultural sites compared with agricultural sites, which was not observed. Spillover occurrence would also have been supported by a strong correlation between disease incidence and agricultural host acreage. Measures of host density, limited to within $1 \mathrm{~km}$ of sample sites, did not support that conclusion. Pathogen incidence appeared driven by the presence of both agricultural and nonagricultural hosts, whose combined acreage produced a marginally better explanatory model of incidence than either group alone. While pathogen movement is most frequently examined in the context of noncultivated hosts contributing to disease in cultivated communities (Blitzer et al. 2012; Power and Mitchell 2004), we found the density of both crops and noncultivated hosts appeared to drive the incidence of this generalist pathogen in grasses. Determining when local conditions sufficiently predict disease risk is important (Ostfeld et al. 2005), and while local context can be a stronger driver of disease than regional context in some cases (Borer et al. 2010), the current study found local land use less relevant than regional host density when predicting pathogen incidence.

No evidence of a dilution or amplification effect was seen in our study. The dilution of disease by increasing host diversity is predicated on having variation in host competency and the abundance of highly susceptible hosts decreasing as host diversity increases (Ostfeld and Keesing 2012). Estimated host species numbers varied across sites, but increasing diversity was not associated with a change in pathogen incidence. While we observed a wide range of pathogen recovery rates from different grass species, the hosts most wellrepresented showed similar levels of disease incidence, indicating little variation in host competency. When sampled from the margins of agricultural fields not treated with fungicide, grasses had a similar rate of infection as the cereal crops observed at the same site. For example, cereal rye at one location had less than $1 \%$ incidence of $F$. graminearum and grasses from this location also had a low incidence of $3.6 \%$. Spring malting barley at another site had no detectable head blight caused by $F$. graminearum while the incidence in grass was only $1.9 \%$. Winter wheat planted in small variety trial plots,

Table 6. Fusarium graminearum incidence in grasses with $\mathrm{n}>100$ and found at 10 or more field sites

\begin{tabular}{lccc}
\hline Host species & Sites & Spikes & Incidence (\%) \\
\hline Bromus inermis & 14 & 512 & 17.58 \\
Dactylis glomerata & 15 & 575 & 27.82 \\
Elymus repens & 15 & 525 & 11.62 \\
Festuca spp. & 15 & 357 & 12.05 \\
Phalaris arundinacea & 17 & 527 & 15.56 \\
Phleum pratense & 16 & 478 & 11.30 \\
Pоа аппиа & 10 & 200 & 7.50 \\
\hline
\end{tabular}

including susceptible and moderately resistant varieties, had an estimated $12 \%$ (range $=5$ to $23 \%$ ) incidence, while the average for all grass spikes collected from this site was essentially the same $(12.4 \%)$. Comprehensive comparisons of host competency are lacking, though controlled experiments on overwintering, spore production, and root rot on wheat and wild grasses (Fulcher et al. 2019) suggested that these hosts are similarly suited to colonization, and preliminary greenhouse experiments suggest virulence on wheat is comparable for both crop and grass derived isolates (Fulcher 2019). The recovery of $F$. graminearum from overwintered grass stem debris revealed levels of pathogen survival indicative of persistence in noncultivated host communities, suggesting these grasses are capable of driving infection cycles in the absence of crop hosts. Because of this, pathogen movement between grasses and crops may occur in both directions.

The current study also presents evidence that regional host density and rainfall are associated with changes in grass-dwelling microbial communities. The prevalence of $F$. graminearum in Fusarium spp. communities increased along with host density and rainfall. This was the case in both agricultural environments as well as in conserved, natural environments. $F$. graminearum is more likely than its congeners to disperse long distances due to its homothallic production of airborne ascospores. All Fusarium spp. are able to generate asexual propagules that are wind- or splash-dispersed over short distances (Paul et al. 2004), but $F$. graminearum sexual spores are known to disperse on a kilometer scale (Keller and Shields 2014; Maldonado-Ramirez et al. 2005). Rainfall is crucial to the production and dispersal of these spores as well as to eventual host infection. The benefit $F$. graminearum receives in high rainfall environments is likely greater than to other Fusarium spp., possibly explaining the corresponding differences in $F$. graminearum-Fusarium spp. ratios observed in this study. While the total incidence of non-graminearum species did not decline with increased $F$. graminearum incidence in the observed years, there could be impacts on species diversity or community structure over time. A more detailed study of changes in these communities is warranted because Fusarium spp. are responsible for other crop diseases and the production of various toxins in agricultural commodities.

The combined findings of this study have implications for the preservation of microbial biodiversity and the management of natural grasslands as well as crop fields. Changes in natural host communities have occurred due to pathogen accumulation and movement between species (Flory and Clay 2013). Situated in a region of moderate agricultural production, the 10,000 -acre wildlife preserve sampled in all three years had $F$. graminearum incidence in grasses and prevalence in Fusarium communities comparable to that of grasses found in nearby agricultural fields. F. graminearum can infect the roots and seedlings of some hosts, and another fungal seed pathogen, Pyrenophora semeniperda, has been shown to alter host community composition in grasses (Beckstead et al. 2010). A related species, Fusarium palustre, is implicated in the dieback of native phragmites and shapes community interactions that include an organism (Sesarma reticulatum) from a higher trophic level (Elmer 2014). Changes occurring in microbial communities due to increased host density, such as that resulting from agricultural expansion, deserve further study, particularly when associated crop pathogens have broad host ranges and can disperse over medium to long distances.

\section{Acknowledgments}

The authors acknowledge extension specialists Keith Severson, Mike Stanyard, and Kitty O'Neil, Chris Nobles and the Uihlein Seed Potato Farm, Mike Davis an Willsboro Research Farm, Linda Ziemba and the Montezuma National Wildlife Refuge, and the small grains producers who made this work possible.

\section{Literature Cited}

Beckstead, J., Meyer, S. E., Connolly, B. E., Huck, M. B., and Street, L. E. 2010. Cheatgrass facilitates spillover of a seed bankpathogen onto native grass species. J. Ecol. 98:168-177.

Blitzer, E. J., Dormann, C. F., Holzschuh, A., Klein, A. M., Rand, T. A., and Tscharntke, T. 2012. Spillover of functionally important organisms between managed and natural habitats. Agric. Ecosyst. Environ. 146:34-43. 
Borer, E. T., Seabloom, E. W., Mitchell, C. E., and Power, A. G. 2010. Local context drives infection of grasses by vector-borne generalist viruses. Ecol. Lett. 13:810-818.

Cardinale, B. J., Duffy, J. E., Gonzalez, A., Hooper, D. U., Perrings, C., Venail, P., Narwani, A., Mace, G. M., Tilman, D., Wardle, D. A., Kinzig, A. P., Daily, G. C., Loreau, M., Grace, J. B., Larigauderie, A., Srivastava, D. S., and Naeem, S. 2012. Biodiversity loss and its impact on humanity. Nature 486: $59-67$.

Elmer, W. H. 2014. A tripartite interaction between Spartina alterniflora, Fusarium palustre, and the purple marsh crab (Sesarma reticulatum) contributes to sudden vegetation dieback of salt marshes in New England. Phytopathology 104:1070-1077.

Fabiszewski, A. M., Umbanhowar, J., and Mitchell, C. E. 2010. Modeling landscape-scale pathogen spillover between domesticated and wild hosts: Asian soybean rust and kudzu. Ecol. Appl. 20:582-592.

Farr, D. F., and Rossman, A. Y. 2019. Fungal Databases, U.S. National Fungus Collections, ARS, USDA. https://nt.ars-grin.gov/fungaldatabases/.

Flory, S. L., and Clay, K. 2013. Pathogen accumulation and long-term dynamics of plant invasions. J. Ecol. 101:607-613.

Flory, S. L., Kleczewski, N., and Clay, K. 2011. Ecological consequences of pathogen accumulation on an invasive grass. Ecosphere 2:art120.

Fulcher, M. R. 2019. Fusarium graminearum at the intersection of wheat and wild grass communities. Ph.D. thesis, Cornell University, Ithaca, NY.

Fulcher, M. R., Garcia, J. P., Damann, K. C. M., and Bergstrom, G. C. 2019. Variable interactions between non-cereal grasses and Fusarium graminearum. Can. J. Plant Pathol. 41:450-456.

Gilbert, G. S. 2002. Evolutionary ecology of plant diseases in natural ecosystems. Annu. Rev. Phytopathol. 40:13-43.

Gilbert, G. S., and Hubbell, S. P. 1996. Plant Diseases and the conservation of tropical forests. Bioscience 46:98-106.

Goswami, R. S., and Kistler, H. C. 2004. Heading for disaster: Fusarium graminearum on cereal crops. Mol. Plant Pathol. 5:515-525.

Hsieh, T. C., Ma, K. H., and Chao, A. 2016. iNEXT : an R package for rarefaction and extrapolation of species diversity (Hill numbers). Methods Ecol. Evol. 7: 1451-1456.

Inch, S., and Gilbert, J. 2003. The incidence of Fusarium species recovered from inflorescences of wild grasses in southern Manitoba. Can. J. Plant Pathol. 25: 379-383.

Keesing, F., Holt, R. D., and Ostfeld, R. S. 2006. Effects of species diversity on disease risk. Ecol. Lett. 9:485-498.

Keller, M. D., Bergstrom, G. C., and Shields, E. J. 2014. The aerobiology of Fusarium graminearum. Aerobiologia Bologna 30:123-136.

Keller, M. D., and Shields, E. J. 2014. Aerobiological sampling efficiency of media-containing Petri plates for use in lower atmosphere spore collection. Aerobiologia Bologna 30:103-109.

Large, E. C. 1954. Growth stages in cereals - illustration of the Feekes scale. Plant Pathol. 3:128-129.

Lefcheck, J. S. 2016. piecewiseSEM: Piecewise structural equation modelling in $\mathrm{r}$ for ecology, evolution, and systematics. Methods Ecol. Evol. 7:573-579.

Leslie, J. F., and Summerell, B. A., eds. 2006. The Fusarium Laboratory Manual. Blackwell Publishing, Ames, IA

Lofgren, L. A., LeBlanc, N. R., Certano, A. K., Nachtigall, J., LaBine, K. M., Riddle, J., Broz, K., Dong, Y., Bethan, B., Kafer, C. W., and Kistler, H. C. 2017. Fusarium graminearum: Pathogen or endophyte of North American grasses? New Phytol. 217:1203-1212.

Maldonado-Ramirez, S. L., Schmale, D. G., Shields, E. J., and Bergstrom, G. C. 2005. The relative abundance of viable spores of Gibberella zeae in the planetary boundary layer suggests the role of long-distance transport in regional epidemics of Fusarium head blight. Agric. For. Meteorol. 132:20-27.

Manstretta, V., Morcia, C., Terzi, V., and Rossi, V. 2016. Germination of Fusarium graminearum ascospores and wheat infection are affected by dry periods and by temperature and humidity during dry periods. Phytopathology 106:262-269.

Manstretta, V., and Rossi, V. 2015. Effects of weather variables on ascospore discharge from Fusarium graminearum perithecia. PLoS One 10:e138860.

Marasas, W. F. O., Nelson, P. E., and Tousser, T. A. 1984. Toxigenic Fusarium species: Identification and Mycotoxicology. The Pennsylvania State University Press, University Park, PA

McMullen, M., Jones, R., and Gallenberg, D. 1997. Scab of wheat and barley: A reemerging disease of devastating impact. Plant Dis. 81:1340-1348.

Meentemeyer, R. K., Rank, N. E., Anacker, B. L., Rizzo, D. M., Hall, J., and Cushman, J. H. 2008. Influence of land-cover change on the spread of an invasive forest pathogen. Ecol. Appl. 18:159-171.

Mordecai, E. A. 2013. Consequences of pathogen spillover for cheatgrass-invaded grasslands: Coexistence, competitive exclusion, or priority effects. Am. Nat. 181:737-747.

Ostfeld, R. S., Glass, G. E., and Keesing, F. 2005. Spatial epidemiology: An emerging (or re-emerging) discipline. Trends Ecol. Evol. 20:328-336.

Ostfeld, R. S., and Keesing, F. 2012. Effects of host diversity on infectious disease. Annu. Rev. Ecol. Evol. Syst. 43:157-182.

Paul, P. A., Lipps, P. E., and Madden, L. V. 2004. Rain splash dispersal of Gibberella zeae within wheat canopies in Ohio. Phytopathology 94:1342-1349.

Plantegenest, M., Le May, C., and Fabre, F. 2007. Landscape epidemiology of plant diseases. J. R. Soc. Interface 4:963-972.

Power, A. G., and Mitchell, C. E. 2004. Pathogen spillover in disease epidemics. Am. Nat. 164(S5):S79-S89.

QGIS Development Team. 2013. QGIS Geographic Information System. Open Source Geospatial Foundation Project. http://qgis.osgeo.org/

R Core Team. 2019. R: A language and environment for statistical computing. R Foundation for Statistical Computing, Vienna, Austria. https://www.Rproject.org/

Salkeld, D. J., Padgett, K. A., and Jones, J. H. 2013. A meta-analysis suggesting that the relationship between biodiversity and risk of zoonotic pathogen transmission is idiosyncratic. Ecol. Lett. 16:679-686

Szécsi, A., Magyar, D., Tóth, S., and Szőke, C. 2013. Poaceae: A rich source of endophytic fusaria. Acta Phytopathol. Entomol. Hung. 48:19-32.

Turkington, T. K., Clear, R. M., Demeke, T., Lange, R., Xi, K., and Kumar, K. 2011. Isolation of Fusarium graminearum from cereal, grass and corn residues from Alberta, 2001-2003. Can. J. Plant Pathol. 33:179-186.

USDA National Agricultural Statistics Service. 2019. Cropland Data Layer. https://nassgeodata.gmu.edu/CropScape/.

Wegulo, S. N., Baenziger, P. S., Hernandez Nopsa, J., Bockus, W. W., and HallenAdams, H. 2015. Management of Fusarium head blight of wheat and barley. Crop Prot. 73:100-107

Wilson, W. W., McKee, G., Nganje, W. E., Dahl, B., and Bangsund, D. A., 2017. Economic impact of USWBSI's scab initiative to reduce FHB. Department of Agribusiness and Applied Economics, North Dakota State University, Fargo, ND. https://scabusa.org/pdfs/AAE774.pdf

Wisler, G. C., and Norris, R. F. 2005. Interactions between weeds and cultivated plants as related to management of plant pathogens. Weed Sci. 53:914-917.

Young, H. S., Parker, I. M., Gilbert, G. S., Sofia Guerra, A., and Nunn, C. L. 2017. Introduced species, disease ecology, and biodiversity-disease relationships. Trends Ecol. Evol. 32:41-54. 